\title{
Colonic secretory effect in response to enteral feeding in humans
}

\author{
T E Bowling, A H Raimundo, G K Grimble, D B A Silk
}

\begin{abstract}
Diarrhoea complicating enteral feeding is a common clinical problem affecting up to $25 \%$ of patients. Its pathogenesis remains unknown. A new technique of human in vivo segmental colonic perfusion was used to investigate colonic water and electrolyte movement in response to enteral feeding. Four groups of studies were performed in which low and high load polymeric enteral diet infusions were undertaken, either intragastrically or intraduodenally ( $n=6$ each group). Net absorption of sodium, chloride, and water occurred during fasting throughout the colon in all groups. There was a significant net secretion of sodium, chloride, and water in the ascending colon during low load (sodium: $-42 \mathrm{mmol} / \mathrm{h} ; 95 \%$ confidence limits -52 to -19 , Chloride: $-18 \mathrm{mmol} / \mathrm{h}$; -50 to +16 , water: -174 $\mathrm{ml} / \mathrm{h} ;-348$ to -30 ) and high load (sodium: $-24 \mathrm{mmol} / \mathrm{h} ;-60$ to +8 , chloride: -18 $\mathrm{mmol} / \mathrm{h}$; -31 to +16 , water: $-120 \mathrm{ml} / \mathrm{h}$; -246 to +6$)$ gastric feeding, and during high load duodenal feeding (sodium: -12 $\mathrm{mmol} / \mathrm{h}$; -22 to -6 , chloride; $-6 \mathrm{mmol} / \mathrm{h}$; -16 to +3 , water: $-72 \mathrm{ml} / \mathrm{h}$; -144 to -6 ). Net secretion persisted in the distal colon only during high load gastric feeding. In the other three groups there was a net absorption in the distal colon. This study identified a significant colonic secretory response to enteral feeding, which is related to the site and load of the diet infusion. This response may play an important part in the pathogenesis of enteral feeding related diarrhoea. (Gut 1994; 35: 1734-1741)
\end{abstract}

Diarrhoea is the commonest complication of enteral feeding, occurring in up to $25 \%$ of patients in general medical and surgical wards. ${ }^{1}$ This not only limits the efficacy of enteral feeding, but will add to potential complications, distress both patients and staff, and increase costs. ${ }^{2} \mathrm{~A}$ number of factors have been implicated in the pathogenesis of this diarrhoea, and these include infusion of infected diet, lactose intolerance, ${ }^{3}$ concomitant antibiotic treatment, ${ }^{45}$ and coexisting hypoalbuminaemia. ${ }^{67}$ Attention to these factors has reduced the incidence of diarrhoea, but still occurs, in our experience, in at least $15 \%$ of patients (D B A Silk, unpublished data).

To achieve a greater understanding of the pathogenesis of enteral feeding related diarrhoea we have recently examined the possibility of a disturbance in small intestinal function. ${ }^{89}$ In these studies small intestinal function during the intraduodenal infusion of a polymeric enteral diet differed from that seen after intragastric infusion. In the first, the small intestinal motility was converted appropriately from the 'fasting' to the 'fed' pattern; the volume of water and electrolytes entering the colon (colonic in flow) was increased from fasting values; but no subjects developed diarrhoea. During intragastric diet infusion, however, small intestinal motility remained in the 'fasting' pattern and colonic inflows were decreased; nevertheless most subjects developed diarrhoea. ${ }^{10}$ These data suggest firstly that enteral feeding related diarrhoea will probably occur more often during intragastric than intraduodenal feeding, and secondly that it will probably occur as a consequence of disturbances in colonic rather than small intestinal function.

The aim of this study, therefore, was to find out if a disturbance of colonic absorptive function is the primary aetiological factor of enteral feeding related diarrhoea. To do this we have modified the technique of human in vivo steady state colonic perfusion, first described in $1962,{ }^{11}$ so as to permit the measurement of colonic in flow volumes and, by including an additional aspiration port at the hepatic flexure, segmental water and electrolyte handling in the ascending and distal colon. This technique has been reviewed in detail elsewhere. ${ }^{12}$

\section{Methods}

\section{PERFUSION TUBE}

The method of in vivo steady state colonic perfusion used is a modification of the four lumen technique described by Devroede and $N$ Phillips. ${ }^{13}$ The tube comprises seven lengths of N polyvinyl tubing cemented with tetrahydro- $\bar{\sigma}$ fluoran, with internal diameters ranging from $0.6-1.5 \mathrm{~mm}$.

Colonic in flow volumes were calculated from the dilution of a non-absorbable marker infused under steady state conditions through a $20 \mathrm{~cm}$ segment of the terminal ileum just proximal to the ileocaecal valve. We assessed colonic segmental water and electrolyte movement by infusing a second non-absorbable marker into the caecum and sampling at the hepatic flexure and rectum. Moving from the proximal to the distal end of the tube (Fig 1), therefore, port 1 is used for the infusion of a non-absorbable marker into the proximal end of the $20 \mathrm{~cm}$ terminal ileal test segment, port 2 is an air bleed to assist aspiration of ileal contents from port 3 , both $20 \mathrm{~cm}$ distal to port 1 . The colonic perfusate is infused into port 4 \\ Department of
Gastroenterology and \\ Middlesex Hospital, \\ Tondon \\ A H Raimundo \\ G K Grimble
}




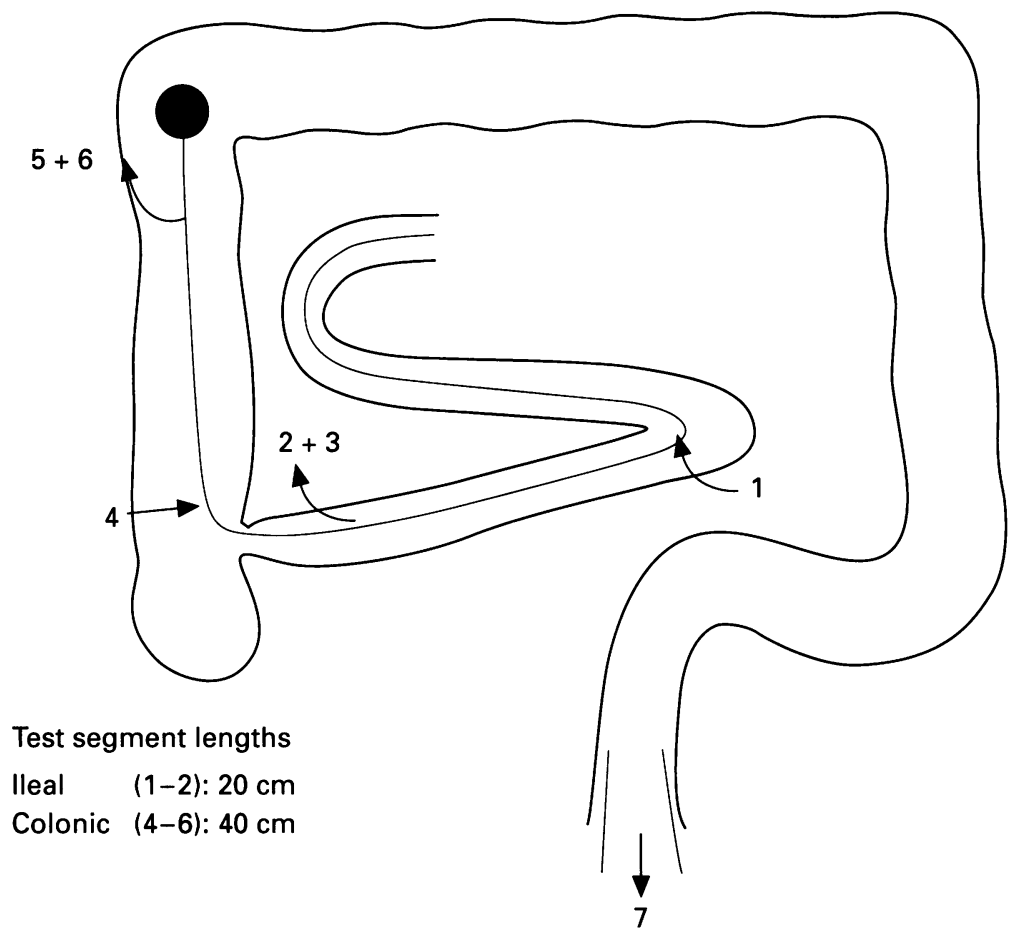

1 lleal infusion

2 Air bleed

3 lleal aspirate

4 Caecal infusion

5 Air bleed

6 Ascending colonic aspirate

7 Rectal sample via tube

Figure 1: Diagramatic representation of orocolonic perfusion tube.

sited in the caecum and $15 \mathrm{~cm}$ distal to port 3. Port 5 is an air bleed to assist aspiration of ascending colonic contents from port 6 , sited at the hepatic flexure $40 \mathrm{~cm}$ distal to port 4 . The seventh channel is used to inflate a balloon at the tip of the tube containing a mercury weight, which has been shown to accelerate the passage of the tube through the small intestine. ${ }^{14}$

\section{EXPERIMENTAL TECHNIQUE}

The experimental technique has been described in detail elsewhere. ${ }^{12}$

Twenty four studies were carried out in healthy volunteers with no history of gastrointestinal disease or metabolic disorders. Approval was granted by the Parkside Health Authority ethics committee.

After an overnight fast the subjects were intubated with the seven lumen tube receiving no sedation, and it was allowed to pass down so that the distal end was just proximal to the hepatic flexure of the colon. A small balloon was inflated at the distal end of the tube to accelerate its passage through the small intestine. It took between 15 and 21 hours for the tube to reach its final position, which was verified fluoroscopically. In addition to this orocolonic tube six subjects were intubated with a nasogastric feeding tube $(6 \mathrm{FG}, 93 \mathrm{~cm}$; Corpak, Illinois, US) and six with nasoduodenal tube (8 FG, $109 \mathrm{~cm}$; Corpak, Illinois, US).

Once correctly sited in the colon $0.9 \%$ normal saline was infused at $16 \mathrm{ml} / \mathrm{min}$ for two hours at $37^{\circ} \mathrm{C}$ through port 4 to flush the colon free of faecal material. At the same time the test solution for the terminal ileal segment, containing $0.5 \mu \mathrm{Ci} / 1{ }^{3} \mathrm{H}$ polyethylene glycol 4000 (PEG) as the non-absorbable marker in $150 \mathrm{mmol} / 1 \mathrm{NaCl}$, was infused into port 1 at $1 \mathrm{ml} / \mathrm{min}$ by means of a peristaltic pump. Two hours was allowed to attain a steady state of absorption, defined as a variation between ${ }^{3} \mathrm{H}$ counts of less than $5 \% .{ }^{131516}$ Thereafter aspirates were collected every 20 minutes from port 3 for the duration of the study. The first $1 \mathrm{ml}$ of these aspirates was discarded, as this was the calculated dead space within the tube, and the subsequent $1 \mathrm{ml}$ was kept for analysis.

Once the colon had been flushed of faecal material, a soft 24 FG tube was placed in the rectum. The test solution for the colon, containing $0.5 \mu \mathrm{Ci} / 1{ }^{14} \mathrm{C}$ PEG 4000 in an iso-osmotic electrolyte solution with a $\mathrm{pH}$ of 6.8-7.1 $\mathrm{Na}^{+} 140 \mathrm{mM} ; \mathrm{K}^{+} 5 \mathrm{mM} ; \mathrm{Cl}^{-}$ $120 \mathrm{mM} ; \mathrm{HCO}_{3}{ }^{-} 25 \mathrm{mM}$ ) was infused into port 4 at $10 \mathrm{ml} / \mathrm{min}$ by means of a peristaltic pump. Again two hours of colonic infusion was allowed to reach a steady state of absorption, after which three collections at 10 minute intervals were taken from port 6 and the rectal fluid. The first $5 \mathrm{ml}$ of each port 6 aspirate (calculated dead space) was discarded and the subsequent $2 \mathrm{ml}$ kept for analysis. The rectal effluent, however, was allowed to drain freely, from which $5 \mathrm{ml}$ was collected every 10 minutes.

After these fasting collections were made, the infusion of an enteral diet was commenced. In 12 of the studies a low strength enteral feed (Ensure, Cow and Gate, UK; $1.39 \mathrm{ml} / \mathrm{min} ; 1.39$ $\mathrm{kcal} / \mathrm{min} ; 8.75 \mathrm{mgN} / \mathrm{min} ; \mathrm{Na}^{+} 35 \mathrm{mmol} / \mathrm{l}$ ) was infused and in the remaining 12 a high strength feed (Ensure Plus, Cow and Gate, UK; 2.78 $\mathrm{ml} / \mathrm{min} ; 4.2 \mathrm{kcal} / \mathrm{min} ; 26 \cdot 1 \mathrm{mgN} / \mathrm{min} ; \mathrm{Na}^{+} 35$ $\mathrm{mmol} / \mathrm{l}$ ) was infused. The low load diet, if given over 24 hours, would provide $2000 \mathrm{kcal} /$ day (2 $1 /$ day), and therefore equates to what most patients are prescribed. The high load diet provides a similar amount of nutrients to those patients being enterally fed over 12-14 hours/day, a common scenario for home feeding. With each of these diets six subjects were fed intragastrically and six intraduodenally. After two hours of feeding collections from ports 3 and 6 and from the rectal effluent were obtained at 20 minute intervals for four hours, at which stage the study was terminated and the positions of the orocolonic and nasoenteral tubes checked fluoroscopically.

\section{ANALYSIS}

${ }^{3} \mathrm{H}$ and ${ }^{14} \mathrm{C}$ PEG values were measured by double channel liquid scintillation counting (Beckman LS 7500) using the H-number method of determination of quenching.

Electrolyte contents of perfusion solutions and intestinal aspirates were measured by standard automated clinical methods.

\section{CALCULATIONS}

The calculations for determining the colonic in flow volumes and electrolyte concentrations, 
TABLE I Colonic in flow

\begin{tabular}{|c|c|c|c|c|c|c|c|c|}
\hline \multirow{3}{*}{$\begin{array}{l}\text { Water+electrolytes } \\
\text { (median + range) }\end{array}$} & \multicolumn{4}{|c|}{ Low strength enteral diet } & \multicolumn{4}{|c|}{ High strength enteral diet } \\
\hline & \multicolumn{2}{|l|}{ Gastric group } & \multicolumn{2}{|c|}{ Duodenal group } & \multicolumn{2}{|l|}{ Gastric group } & \multicolumn{2}{|c|}{ Duodenal group } \\
\hline & Fasting & Fed & Fasting & Fed & Fasting & Fed & Fasting & Fed \\
\hline Water $(\mathrm{ml} / \mathrm{h})$ & $\begin{array}{l}135^{\star} \\
(96-174)\end{array}$ & $\begin{array}{l}78^{\star} \\
(36-144)\end{array}$ & $\begin{array}{l}120 \\
(108-150)\end{array}$ & $\begin{array}{l}186 \\
(30-246)\end{array}$ & $\begin{array}{l}96 \\
(90-120)\end{array}$ & $\begin{array}{l}108 \\
(96-126)\end{array}$ & $\begin{array}{l}90 \\
(36-108)\end{array}$ & $\begin{array}{l}108 \\
(96-114)\end{array}$ \\
\hline Sodium $(\mathrm{mmol} / \mathrm{h})$ & 141 & 143 & 144 & 151 & 141 & 148 & 142 & 146 \\
\hline Potassium (mmol/l) & $\begin{array}{l}(124-152) \\
4 \cdot 7 \\
(4 \cdot 3-5 \cdot 2)\end{array}$ & $\begin{array}{l}(128-152) \\
4 \cdot 9 \\
(4 \cdot 6-5 \cdot 0)\end{array}$ & $\begin{array}{l}(132-161) \\
4 \cdot 8 \\
(4 \cdot 3-5 \cdot 2)\end{array}$ & $\begin{array}{l}(147-162) \\
4 \cdot 9 \\
(4 \cdot 0-6 \cdot 0)\end{array}$ & $\begin{array}{l}(126-149) \\
4 \cdot 4 \\
(3 \cdot 7-4 \cdot 7)\end{array}$ & $\begin{array}{l}(143-154) \\
4 \cdot 8 \\
(4 \cdot 2-5 \cdot 7)\end{array}$ & $\begin{array}{l}(136-150) \\
4 \cdot 8 \\
(4 \cdot 3-5 \cdot 9)\end{array}$ & $\begin{array}{l}(141-162) \\
5 \cdot 7 \\
(4 \cdot 3-7 \cdot 1)\end{array}$ \\
\hline Chloride $(\mathrm{mmol} / \mathrm{l})$ & 125 & 120 & 125 & 126 & 122 & 118 & 116 & 112 \\
\hline Bicarbonate $(\mathrm{mmol} / \mathrm{l})$ & $27(22-31)$ & 25 & 25 & $\begin{array}{l}24 \\
(19-36)\end{array}$ & 21 & $\begin{array}{l}19 \\
(14-25)\end{array}$ & 18 & $22(16-32)$ \\
\hline
\end{tabular}

and the ascending and distal colonic water and electrolyte flows have been reviewed in detail elsewhere, ${ }^{12}$ and are similar to those used in all the original perfusion studies. ${ }^{11} 16-19$

\section{STATISTICAL ANALYSIS}

The primary analysis was planned to be a comparison of the colonic in flow volumes and regional colonic water and electrolyte flows in the fasting and fed states, using the Wilcoxon matched pairs signed rank test. The MannWhitney $U$ test was used to assess the significance of any difference between the group fed intragastrically and the group fed intraduodenally. The secondary analysis was planned to be a comparison of the water and electrolyte movements seen with the different strength diets.

\section{Results}

\section{SUBJECTS}

Twenty four successful studies were performed on 16 subjects (mean age 24; nine male, seven female). There were 12 further studies, unsuccessful usually because of the inability to tolerate the orocolonic tube.

\section{COLONIC IN FLOW (Table 1)}

The presence of ${ }^{14} \mathrm{C}$ PEG in the ileal aspirates permitted the degree of colonic reflux to be calculated. This correction was made because reflux would inappropriately dilute the ileal contents. Reflux occurred in 10 of 24 studies, but in these it never accounted for more than $3.8 \%$ of the total colonic in flow volume. Nevertheless, the calculations were corrected to take this into account.

During the infusion of the low strength diet there was a significant fall in the mean colonic in flow of water in those fed intragastrically: $135 \mathrm{ml} / \mathrm{h}$ during fasting to $78 \mathrm{ml} / \mathrm{h}(\mathrm{p}<0.05)$; and in those fed intraduodenally the in flow was greater $(186 \mathrm{ml} / \mathrm{h})$, although this did not reach statistical significance. These changes, however, were not seen during the infusion of the high strength diet, where the colonic in flows were similar both between fasting and fed states, and between the gastric and duodenal groups.

The electrolyte concentrations in the colonic in flows were similar both between the four groups and between the fasting and fed $\vec{\omega}$ periods.

\section{ASCENDING COLON}

Water (Fig 2)

In the fasting state water was absorbed in all $\mathrm{O}$ groups at similar rates, with median values varying between +42 and $+120 \mathrm{ml} / \mathrm{h}$. A net secretion was seen, however, during the intragastric infusion of both low and high strength 3 diets ( -174 and $-120 \mathrm{ml} / \mathrm{h}$ respectively) and 은 during the intraduodenal infusion of the high $\vec{\theta}$ strength diet $(-72 \mathrm{ml} / \mathrm{h})$. These rates of secretion were significantly different both from fasting values and from the net absorption that continued during the intraduodenal low load infusion $(\mathrm{p}<0.05)$.

\section{Electrolytes (Table II)}

Sodium and chloride movement was similar to water movement in all four groups. There was thus a significant net secretion during the intragastric infusion of both diets and during the intraduodenal infusion of the high strength diet, and a net absorption during low load intraduodenal feeding.

Bicarbonate, as expected, ${ }^{20}$ was secreted throughout the study in all four groups. Potassium was secreted during feeding in all groups, and at significantly greater rates during the high load infusions.

\section{DISTAL COLON}

\section{Water (Fig 3)}

There was a net absorption of water during fasting in all groups, varying between +30 and $\frac{T}{3}$ $+72 \mathrm{ml} / \mathrm{h}$. This absorption continued during low load feeding (gastric group: $+84 \mathrm{ml} / \mathrm{h}$; duodenal group: $+78 \mathrm{~m} / \mathrm{h}$ ) and during the intraduodenal high load feeding $(+12 \mathrm{ml} / \mathrm{h})$. However, during the intragastric high load 8 feeding there was a net secretion of $-12 \mathrm{ml} / \mathrm{h}$. There were no significant differences between $\bar{c}$ these results.

\section{Electrolyte (Table II)}

Again, sodium and chloride movement was similar to that seen with water. There was a statistical difference $(p<0.05)$ in the absorption 

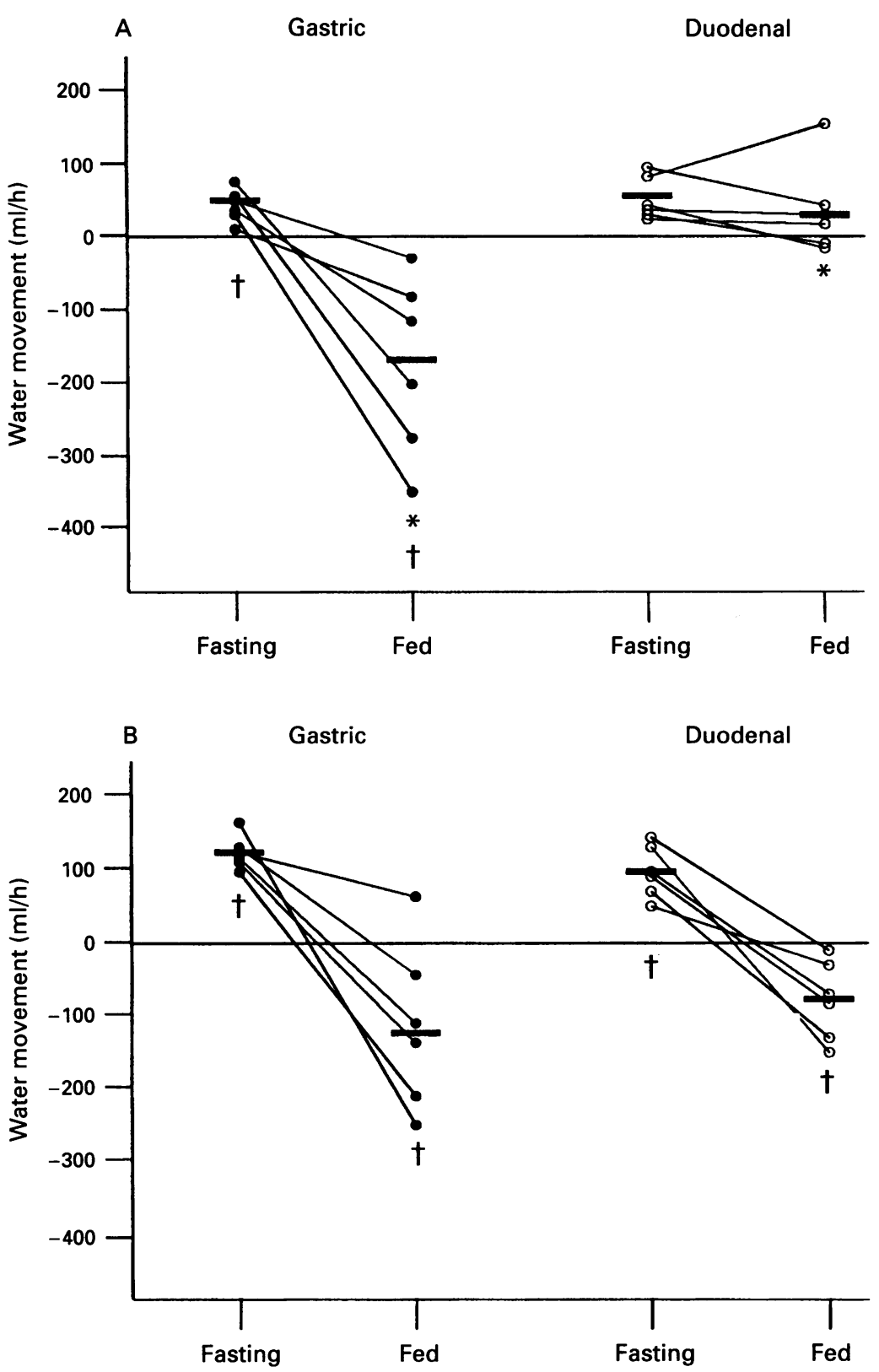

Figure 2: Water movement in the ascending colon with $(A)$ low strength diet and $(B)$ high strength diet. Each point represents a subject; the thick lines are the medians. $\mathbf{O}=$ Gastric feeding, $\mathrm{O}=$ duodenal feeding, $+=$ net absorption, $-=$ net secretion. ${ }^{\star}=$ Gastric $\mathrm{v}$ duodenal $p<0.05 ; \dagger=$ fasting $\vee$ fed $p<0.05$. of sodium between the fasting $(+12 \mathrm{mmol} / \mathrm{h})$ and the intragastric low load feeding $(+48$ $\mathrm{mmol} / \mathrm{h}$ ), and also with the secretion of sodium seen during the high load duodenal feeding $(-6 \mathrm{mmol} / \mathrm{h} ; \mathrm{p}<0.05)$. The movement of chloride was similar to that of sodium, although there were no significant changes at any stage.

Potassium and bicarbonate were secreted throughout the study, except for an absorption during the low load duodenal feeding (potassium: $+1.2 \mathrm{mmol} / \mathrm{h}$; bicarbonate: +6 $\mathrm{mmol} / \mathrm{h}$ ). These absorption values were similar to fasting values, but were statistically different from the secretion seen during low load intragastric feeding $(p<0 \cdot 05)$. The secretion of bicarbonate during high load diet infusion was significantly greater than during fasting in both groups.

\section{Discussion}

The technique of in vivo human colonic perfusion is not new, having first been described in $1962 .{ }^{11}$ It entails perfusing the colon with an electrolyte solution containing a nonabsorbable marker and collecting the rectal effluent. This permits the determination of water and electrolyte movement in the entire colon to be established, providing a steady state of absorption has been achieved. In three individual experiments in the original study ${ }^{11}$ additional aspirates were taken from the midcolon, as well as from the rectum, to permit determination of fluid movement in the proximal and distal colon. Unfortunately, in these experiments, no allowances were made for the endogenous fluid entering the colon (colonic in flow), and hence their calculations for colonic water and electrolyte movement were open to some question. Nevertheless, the results did imply that water and electrolyte movement varied in different regions of the colon. This is in agreement with other in vivo studies showing regional differences in fluid absorption. $^{2122}$ We therefore modified the existing techniques of colonic perfusion to permit regional assessment of fluid movement in the ascending and distal colon. ${ }^{12}$

TABLE II Electrolyte movement in the colon

\begin{tabular}{|c|c|c|c|c|c|c|c|c|}
\hline \multirow{3}{*}{$\begin{array}{l}\text { Electrolytes } \\
(\text { median } \\
(\text { mmolh }))\end{array}$} & \multicolumn{4}{|l|}{ Low strength diet } & \multicolumn{4}{|l|}{ High strength diet } \\
\hline & \multicolumn{2}{|l|}{ Gastric $(n=6)$} & \multicolumn{2}{|l|}{ Duodenal $(n=6)$} & \multicolumn{2}{|l|}{ Gastric ( $n=6)$} & \multicolumn{2}{|l|}{ Duodenal $(n=6)$} \\
\hline & Fasting & Fed & Fasting & Fed & Fasting & Fed & Fasting & Fed \\
\hline \multicolumn{9}{|l|}{ Ascending colon } \\
\hline Sodium & $+18^{\star}$ & $-42^{\star} t$ & +12 & $+12+5$ & $-18 \ddagger$ & $-24 \dagger$ & $+12 \ddagger$ & $-12 \neq \varsigma$ \\
\hline & $(+10$ to +29$)$ & $(-52$ to -19$)$ & $(+4$ to +20$)$ & $(+3$ to +16$)$ & $(+16$ to +28$)$ & $(-60$ to +8$)$ & $(+5$ to +23$)$ & $(-22$ to -6$)$ \\
\hline Potassium & $\begin{array}{l}-0.12 \\
(-1.8 \text { to }+0.1)\end{array}$ & $\begin{array}{l}-0.72 \\
(-1.8 \text { to }+0.7)\end{array}$ & $\begin{array}{l}+0.06 \\
(-0.7 \text { to }+0.8)\end{array}$ & $\begin{array}{l}-0.24 \\
(-1.0 \text { to }+0.4)\end{array}$ & $\begin{array}{l}+1.8 \neq \\
(-0.2 \text { to }+0.8)\end{array}$ & $\begin{array}{l}-1.2 \dagger \\
(-2.4 \text { to }-0.5)\end{array}$ & $\begin{array}{l}-0.3 \ddagger \\
(-1.5 \text { to }+1.2)\end{array}$ & $\begin{array}{l}-1 \cdot 8 \neq \\
(-3.6 \text { to }-0.1)\end{array}$ \\
\hline Chloride & $\begin{array}{l}+18 \\
(+2 \text { to }+30)\end{array}$ & -18 & $\begin{array}{l}+18 \\
(+7 \text { to }+30)\end{array}$ & $\begin{array}{l}+15^{\star} s \\
(+5 \text { to }+23)\end{array}$ & $\stackrel{+18}{(+12 \text { to }+30)}$ & $\stackrel{-18}{(-31 \text { to }+16)}$ & $\begin{array}{l}+18 \ddagger \\
(+13 \text { to }+22)\end{array}$ & $\begin{array}{l}-6 \neq 5 \\
(-16 \text { to }+3)\end{array}$ \\
\hline Bicarbonate & -6 to -2$)$ & -6 & $\begin{array}{l}+0 \cdot 6 \neq \\
(-5 \text { to }+4)\end{array}$ & $\begin{array}{c}-3 \cdot 6 \neq \\
(-9 \text { to }+2)\end{array}$ & $\begin{array}{l}-1 \cdot 2 \neq \\
(-2 \text { to }+0 \cdot 1)\end{array}$ & $\begin{array}{r}-12 t \\
(-14 \text { to }-4)\end{array}$ & $\begin{array}{l}-6 \\
(-7 \text { to }-2)\end{array}$ & $\begin{array}{l}-6 \\
(-14 \text { to }-2)\end{array}$ \\
\hline \multirow{2}{*}{$\begin{array}{l}\text { Distal colon } \\
\text { Sodium }\end{array}$} & & & & & & & & \\
\hline & $\begin{array}{l}+12 \ddagger \\
(+4 \text { to }+27)\end{array}$ & $\begin{array}{r}-48 \neq 5 \\
(+18 \text { to }+76)\end{array}$ & $\stackrel{+18}{(+7 \text { to }+35)}$ & $\begin{array}{l}+248 \\
(+7 \text { to }+52)\end{array}$ & $\stackrel{+6}{(+4 \text { to }+18)}$ & $\begin{array}{l}-65 \\
(-13 \text { to }+11)\end{array}$ & $\begin{array}{l}+12 \ddagger \\
(+3 \text { to }+23)\end{array}$ & $\begin{array}{l}-6 \neq 5 \\
(-6 \text { to }+5)\end{array}$ \\
\hline Potassium & $\begin{array}{l}-1.8 \\
(-4.2 \text { to }+0.3)\end{array}$ & $\begin{array}{l}-0.6^{\star} \\
(-1 \cdot 7 \text { to }+0.1)\end{array}$ & $\begin{array}{l}+1.2 \\
(-0.8 \text { to }+0.4)\end{array}$ & $\begin{array}{l}+1 \cdot 2^{\star} \\
(-0 \cdot 4 \text { to }+2 \cdot 2)\end{array}$ & $\begin{array}{l}-1.2 \\
(-2.4 \text { to }-0.1)\end{array}$ & $\begin{array}{l}-1.2 \\
(-5.4 \text { to }-0.1)\end{array}$ & $\begin{array}{l}-0.6 \\
(-1.4 \text { to }-0.2)\end{array}$ & $\begin{array}{l}-1.8 \\
(-2.4 \text { to }+1.2)\end{array}$ \\
\hline Chloride & +12 & +425 & $\begin{array}{l}+6 \\
+4+40+10)\end{array}$ & +24 & $\begin{array}{l}+125 \\
(+3 \text { to }+21)\end{array}$ & +6 & +12 & $\begin{array}{l}+6 \\
(-13 \text { to }+55)\end{array}$ \\
\hline Bicarbonate & $\begin{array}{l}-3 \\
(-6 \text { to }-0.6)\end{array}$ & $\begin{array}{l}-6^{\star} \\
(-15 \text { to }-2)\end{array}$ & $\begin{array}{l}-1 \cdot 2 \\
(-5 \text { to }+2)\end{array}$ & $\begin{array}{l}+6 * 5 \\
(-0.5 \text { to }+13)\end{array}$ & $\begin{array}{l}-3.6 \neq \\
(-8 \text { to }-0.5)\end{array}$ & $\begin{array}{r}-12 t \\
(-22 \text { to }-5)\end{array}$ & $\begin{array}{l}-3 \neq \\
(-5 \text { to }+4)\end{array}$ & $\begin{array}{l}-7 \cdot 8 \neq 5 \\
(-11 \text { to }-4)\end{array}$ \\
\hline
\end{tabular}

$+=$ Net absorption, $-=$ net secretion. ${ }^{\star}=$ Gastric $v$ duodenal: $\mathbf{p}<0.005$ (same diet); $\dagger=$ Gastric $v$ duodenal: $\mathbf{p}<0 \cdot 01$ (same diet). $\ddagger=$ Fasting $v$ fed: $p<0 \cdot 05$ (same diet), $\S=$ high $v$ low strength diet: $\mathrm{p}<0 \cdot 01$. 

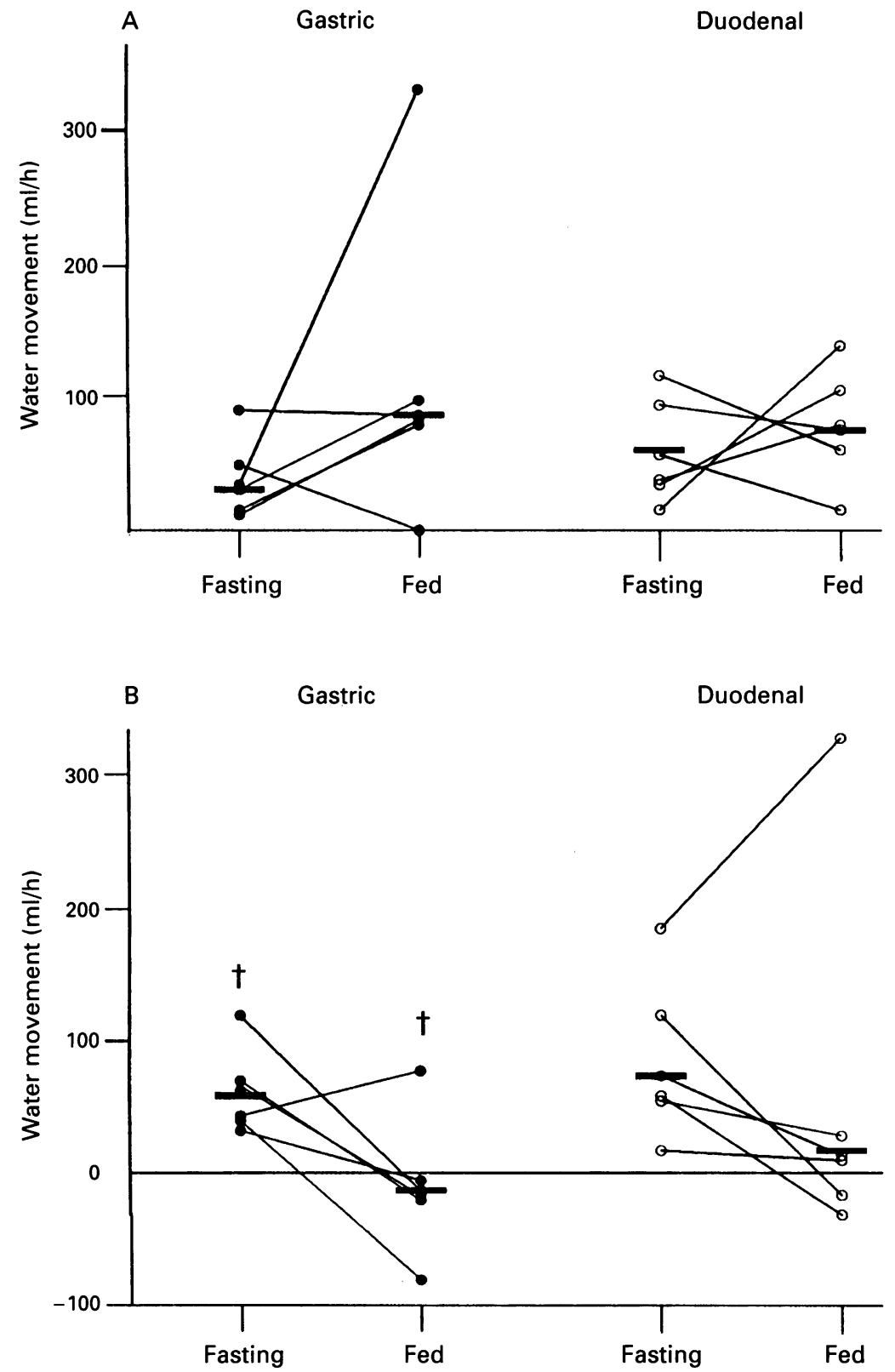

Figure 3: Water movement in the distal colon with $(A)$ low strength diet and $(B)$ high strength diet. Each point represents a subject; the thick lines are the medians. $=$ Gastric feeding, $\mathrm{O}=$ duodenal feeding, $+=$ net absorption, $-=$ net secretion. $+=$ fasting $\mathrm{v}$ fed $p<0.05$. intestinal infusion of an enteral diet induced a hormonally mediated ileal or colonic water and electrolyte secretion. ${ }^{25}$ In retrospect, however, there may have been a fundamental flaw in the experimental design of these studies: the entire colon had been perfused, and hence regional differences in fluid movement could not be assessed. In later studies, Raimundo et al undertook detailed investigation of the small intestinal response to enteral feeding. ${ }^{89}$ They found that during intraduodenal feeding the small intestinal motility appropriately converted from the fasting to the fed pattern, and the colonic in flow volumes were increased from fasting values, although well within the normal absorptive capacity of the colon. These subjects did not develop diarrhoea. During intragastric feeding, however, the motility remained in the fasting state and the colonic in flow volumes were similar to fasting, but most of these subjects developed diarrhoea. ${ }^{10}$ More recently, various investigators have confirmed a pro-absorptive response to meal ingestion, which is independent of nutrient composition, responds to the osmolality of poorly absorbed solutes, and originates at or distal to the duodenum. ${ }^{26}$ Therefore, on the basis of these various findings, it was concluded that enteral feeding related diarrhoea probably occurs as a result of a colonic abnormality.

To our knowledge no other studies have examined the possibility of a colonic basis to enteral feeding related diarrhoea. Using our experimental design we have, for the first time, shown a colonic secretion of water and electrolytes during the enteral infusion of a polymeric diet. This secretion occurs predominantly in the ascending colon, and seems to be dependent on both the site and load of diet infusion. During gastric feeding there is a generalised secretory response (except in the distal colon with the low load diet), which is more noticeable in the ascending colon. Whereas, during duodenal feeding a significant secretion is only seen in the ascending colon with the high load diet.

During the infusion of the low load diets there was an overall absorption in the distal colon of salt and water in both groups. During the infusion of the high load diets, however, there was a median net secretion of $-14.4 \mathrm{ml} / \mathrm{h}$ in the distal colon during gastric feeding, which was significantly different from that seen with the low load diet $(+96 \mathrm{ml} / \mathrm{h})$; and in the duodenal fed group there was a net absorption of $+12 \mathrm{ml} / \mathrm{h}$ in the distal colon, which was considerably less, although not significantly different, from the low load group $(+78 \mathrm{ml} / \mathrm{h})$. It has been shown in separate studies on normal human subjects that infusing an identical low load enteral diet, either intragastrically or intraduodenally, is unlikely to induce diarrhoea. ${ }^{27}$ Whereas infusing an identical high load diet induces diarrhoea in five of six subjects fed intragastrically and only one of six fed intraduodenally. ${ }^{28}$ This would imply that with the low load diet the absorption of salt and water in the distal colon is often sufficient to compensate for the proximal colonic secretion, but with the high load diet there is 
inadequate distal absorption. Our study design did not permit the colonic volumes to be measured, as this would have necessitated extracting all the fluid from the hepatic flexure (not possible in practice) and infusing a fresh solution, and therefore we can only look at overall colonic water movement by combining the flows in the ascending and distal colon. On this basis, in the gastric group there was an overall median colonic secretion of $-84 \mathrm{ml} / \mathrm{h}$ (equivalent to a colonic load of two litres over a 24 hour period) and $-134.4 \mathrm{ml} / \mathrm{h}(3.2$ litres/day) in the low and high load diets respectively; and in the duodenal group a net absorption of $+108 \mathrm{ml} / \mathrm{h}$ and $-60 \mathrm{ml} / \mathrm{h}(1.4$ litres/day) respectively. While the colonic capacity may be able to contain the extra fluid and prevent diarrhoea during intraduodenal and low load intragastric feeding, it is not surprising that it cannot cope with an excess of three litres during high load gastric feeding, and hence invariably lead to diarrhoea.

The total colonic inflow volumes in this study are equivalent to those determined elsewhere. $^{813151719}$ After intraduodenal low load feeding the in flow volumes do increase, although not reaching statistical significance from fasting values, but after low load intragastric feeding there is a significant fall in colonic in flow from 135 to $78 \mathrm{ml} / \mathrm{h}$. This phenomenon has been seen previously, ${ }^{8}$ but the pathogenetic mechanisms underlying it remain unexplained. These changes, however, were not seen during the high load feeding, where no significant differences between the two groups were noted.

The finding that sodium and chloride movement is similar and potassium and bicarbonate movement is, in general opposite to water movement is in agreement with other colonic perfusion studis. ${ }^{192029}$ Devroede and Phillips performed extensive human in vivo perfusion studies with various electrolyte solutions. ${ }^{20}$ They found a good correlation between water, sodium, and chloride movement, irrespective of the solution used. They also saw that, in the presence of chloride, bicarbonate was secreted when infused in concentrations of $25 \mathrm{mM}$ or less. Potassium was secreted when a $5 \mathrm{mM}$ solution (made isotonic with mannitol) was infused, but this was in the absence of sodium or bicarbonate. Because of the difference in infusate composition it is therefore difficult to correlate their results of potassium movement with ours. There are, however, no previous studies looking at electrolyte movement in different regions of the colon.

The explanation that this colonic secretory response differs between the gastric and duodenal fed groups and between the two different diets can only be speculative. The colonic motility in response to the infusion of an identical low load enteral diet, either intragastrically or intraduodenally, does not change from the fasting state, ${ }^{27}$ whereas during high load feeding the segmental pressure activity is suppressed irrespective of the site of feeding. ${ }^{28}$ Motility abnormalities cannot, therefore, be the explanation of the observed differences in colonic water and electrolyte movement.
Presumably a neurohumoral mechanism is initiated in the proximal gastrointestinal tract. One possible explanation is that the receptors controlling the colonic response to feeding are situated in both the stomach and duodenum. During intragastric feeding there may be stimulation of receptors while the diet is retained in the stomach, and this may explain why there is a more profound secretory effect during intragastric feeding. Our studies were designed to examine the 'end-organ' - that is, colonic - responses to enteral feeding, and not to look for the presence and function of receptors in the proximal gastrointestinal tract that may initiate such responses. Chemoreceptors in the proximal gastrointestinal tract have been shown to respond to osmolality, ${ }^{26}$ fat, ${ }^{30}{ }^{31}$ glucose, ${ }^{32}$ and protein, ${ }^{33}$ and distension has been shown to be an effective stimulus of secretion. ${ }^{34} 35$ Any of these factors may play an important part in the colonic responses to enteral feeding.

Once the receptors are stimulated it is likely that a neural or hormonal signal, or both, then brings about the various small and large intestinal responses that have been seen. The only hormone known to cause a colonic secretion of water and electrolytes is vasoactive intestinal polypeptide. ${ }^{36-39}$ In a recent study by Schubert et al vasoactive intestinal polypeptide secretion was induced to $180 \%$ of basal values during in vitro distension of rat stomachs to only $10 \%$ of normal feeding capacity. ${ }^{40}$ Pancreatic peptide, neuropeptide $Y$, and peptide $Y Y, 4142$ vasopressin and somatostatin ${ }^{43}$ have all been shown to stimulate colonic absorption of water and electrolytes in in vitro animal studies. There have been, to our knowledge, no studies looking at hormonal effects on the colon in humans. The enteric nervous system also undoubtedly plays an important part in ion transport in the colon, and electrolyte secretion has been shown on more than one occasion in the in vitro human colon by electrical stimulation. ${ }^{44} 45$ There are very few in vivo human studies looking at colonic function and, before these experiments, there have been no studies examining the colonic responses to enteral feeding. Therefore, on the basis of current knowledge, it is difficult to hypothesise on the mechanisms underlying the colonic secretion that has been shown during enteral feeding.

In our studies it would have been preferential to use six subjects four times - once for each study - so as to reduce the element of intersubject variability when comparing the four groups. There were two subjects who did undergo all four studies and one who did three, but it was assumed at the outset that these studies would not attract subjects on more than one occasion. In these three subjects the observed differences in colonic water and electrolyte movement were similar to the overall results.

We acknowledge that our experimental findings in normal healthy volunteers may not necessarily equate with ill patients requiring nutritional support. Unfortunately, because of the nature of the perfusion studies it is unlikely 
that ethical approval would ever be granted to study patients. In addition, we accept that there are methodological problems with perfusion experiments, which can never be entirely physiological. The interpretation of perfusion techniques requires the establishment of a steady state of absorption. A true steady state will always be impossible to achieve, because of the inconsistencies of gut motility and intestinal diameter and irregular secretion or absorption over any intestinal segment. The accepted definition of a steady state is that the variation in marker concentrations should be less than $5 \%, 1315$ and this has been achieved in these studies. The volunteers are subjected to an uncomfortable oral tube, which remains in situ for 36 hours; the perfusate is infused at rates well above normal physiological flows; and the studies only last for six hours of feeding. Unfortunately, the experimental design was limited to a certain degree by the extent of human endurance, and lower perfusion rates would have made both aspirating samples and the achievement of a steady state more difficult. The above criticisms were thus all anticipated but, after detailed consideration, we do not feel that the experimental design could have been significantly improved. One final question that arises is whether the colonic secretion seen during enteral feeding was related to the prolonged intubation in itself. We feel that this is unlikely because of the consistent differences in observed colonic water and electrolyte movement during intragastric and intraduodenal feeding, and for this reason we believe that the colonic secretion is a genuine response to enteral feeding.

In conclusion we have shown for the first time a colonic secretion of salt and water during enteral feeding using a modified technique of in vivo human segmental colonic perfusion. We believe that these findings are of considerable importance in understanding the underlying pathogenesis of enteral feeding related diarrhoea.

This study was financed by a grant from the Sir Jules Thorn Charitable Trust.

1 Jones BJM, Lees R, Andrews J, Frost P, Silk DBA. Comparison of an elemental and polymeric enteral diet in patients with normal gastrointestinal function. Gut 1983; 24: 78-84

2 Dobb GJ. Diarrhoea in the critically ill. Intensive Care Med 1986; 12: 113-5.

3 O'Keefe SJD, Adam JK, Cakata E, Epstein S. Nutritional support of malnourished lactose intolerance in African patients. Gut 1984; 25: 94-7.

4 Silk DBA. Towards the optimization of enteral nutrition. Clin Nutr 1987; 6: 61.

5 Keohane PP, Attrill H, Love M, Frost P, Silk DBA. Relation between osmolality and gastrointestinal side effects in enteral nutrition. $B M \mathcal{F} 1984 ; 288$ : 678-80.

6 Ford EG, Jennings M, Andrassy RJ. Serum albumin (oncotic pressure) correlates with enteral feeding tolerance in the pediatric surgical patient. $₹$ Pediat Surg tolerance in the pedia

7 Waitzberg D, Teixera de Silva ML, Borges VC. Factors associated with diarrhoea in tube fed patients. Role of serum albumin concentration. Clin Nutr 1988; 7 (suppl 1): 58 .

8 Raimundo AH, Rogers J, Grimble GK, Cahill E, Silk DBA. Colonic inflow and small bowel motility during intraduodenal enteral nutrition. Gut 1988; 29: A1469-70.

9 Raimundo AH, Rogers J, Spiller RC, Grimble G, Silk DBA. Effect of continuous intraduodenal enteral feeding on human colonic in-flow volumes and small bowel motility. Gastroenterology 1989; 404. 96A.
10 Raimundo AH, Rogers J, Silk DBA. Is enteral feeding related diarrhoea initiated by an abnormal colonic response to intragastric diet infusion? Gut 1990; 31: A1195.

11 Levitan R, Fordtran JS, Burrows BA, Ingelfinger FJ. Water and salt absorption in the human colon. $\mathcal{F}$ Clin Invest 1962; 41: 1754-9.

12 Bowling TE, Raimundo AH, Silk DBA. In vivo segmental colonic perfusion in man: A new technique. Eur $\mathcal{f}$ Gastroenterol Hepatol 1993; 5: 809-15.

13 Devroede GJ, Phillips SF. Studies of the perfusion technique for colonic absorption. Gastroenterology 1969; 56: 92-100.

14 Sladen GE, Dawson AM. Effects of flow rate on the absorption of glucose in a steady state perfusion system in man. Clin Science 1969; 36: 133-45.

15 Ruppin H, Bar-Meir S, Soergel KH, Wood CM, Schmitt MG. Absorption of short chain fatty acids by the colon. Gastroenterology 1980; 78: 1500-7.

16 Modigliani R, Rambaud JC, Bernier J. The method of intraluminal perfusion of the human small intestine. Digestion 1973; 9: 176-92.

17 Whalen GE, Harris JA, Geenen JE, Soergel KH. Sodium and water absorption from the human small intestine. Gastroenterology 1966; 51: 975-84.

18 Shields R. Absorption and secretion of electrolytes and water by the human colon, with particular reference to benign adenoma and papilloma. Br $\mathcal{f}$ Surg 1966; 53: 893-7.

19 Phillips SF, Giller J. The contribution of the colon to electrolyte and water conservation in man. $f \mathrm{Lab}$ Clin Med 1973; 81: 733-46.

20 Devroede GJ, Phillips SF. Conservation of sodium, chloride and water by the human colon. Gastroenterology 1969; 56: 101-9.

21 Devroede GJ, Phillips SF, Code CF, Lind JF. Regional differences in rates of insorption of sodium and water from the human large intestine. Can $f$ Physiol Pharmacol 1971; 49: 1023-9.

22 Raab Y, Hallgren R, Knutson L, Krog M, Gerdin B. A technique for segmental rectal and colonic perfusion in humans. Am $\mathcal{F}$ Gastroenterol 1992; 87: 1453-59.22.

23 Wright JP, Barbezat GO, Clain JE. Jejunal secretion in response to a duodenal mixed nutrient perfusion. Gastroenterology 1978; 76: 94-8.

24 Nasset ES, Pierce HB, Murlin JR. Proof of a humoral control of intestinal secretion. Am $\mathcal{F}$ Physiol 1935; 111: $145-51$.

25 Silk DBA, Higgins BE, Spiller RC. Influences of duodenal infusion of Vivonex HN and Ensure on ileal and colonic water and electrolyte absorption in the rat. $\mathcal{f}$ Clin Nutr Gastroenterol 1987; 2: 171-6.

26 Bastidas JA, Orandle MS, Zinner MJ, Yeo CJ. Small-bowel origin of the signal for meal-induced jejunal absorption. Surgery 1990; 108: 376-83.

27 Raimundo AH, Jameson JS, Rogers J, Silk DBA. The effect of enteral nutrition on distal colonic motility. Gastroenterology 1992; 102: A573.

28 Bowling TE, Raimundo AH, Jameson JS, Rogers J, Silk DBA. The effect of enteral feeding on colonic motility in man. Gut 1993; 34 (suppl 1): S33.

29 Rask-Madsen J. Simultaneous measurement of electrical polarization and electrolyte transport by the entire normal and inflamed human colon during in vivo perfusion. Scand 7 Gastroenterol 1973; 8: 327-36.

30 Sircus $\mathbb{W}$. Studies on the mechanisms in the duodenum inhibiting gastric secretion. $Q \mathcal{F}$ Exp Physiol 1958; 43: 114-33.

31 Henriksen FW, Hendel L, Hesseldahl H. Inhibition of gastric secretion by intrajejunal fat. Influence of bile, pancreatic juice, and cholinergic mechanisms. Scand $\mathcal{f}$ Gastroenterol 1976; 11 (suppl 42): 93-5.

32 MacGregor IL, Gueller R, Watts HD, Meyer JH. The effect of acute hyperglycaemia on gastric emptying in man. Gastroenterology 1976; 70: 190-6.

33 Varner AA, Isenberg J, Elashoff JO, Lamers BHW, Maxwell W, Shulkes AA. Effect of intravenous lipid on gastric acid secretion stimulated by intravenous amino acids. Gastroenterology 1980; 79: 873-6.

34 Caren JF, Meyer JH, Grossman MI. Canine intestinal secretion during and after rapid distension of the small bowel. Am $\mathcal{F}$ Physiol 1974; 227: 183-8.

35 Lee JS. Relationship between intestinal motility, tone, water absorption, and lymph flow in the rat. $\mathcal{f}$ Physiol Lond 1983; 345: 489-99.

36 Schwartz CI, Kimberg DV, Sherrin HE, Field M, Said SI. Vasoactive intestinal peptide stimulation of adenylate cyclase and active electrolyte secretion in intestinal mucosa. $¥$ Clin Invest 1974; 54: 536-44.

37 Racusen LC, Binder HJ. Alteration of large intestinal electrolyte transport by vasoactive intestinal polypeptide in the rat. Gastroenterology 1977; 73: 790-6.

38 McCabe RD, Smith PL. Colonic potassium and chloride secretion: role of cAMP and calcium. Am $\mathcal{F}$ Physiol 1985; 248: G103-9.

39 McCulloch CR, Kuwahara A, Condon CD, Cooke HJ Neuropeptide modification of chloride secretion in guinea pig distal colon. Regul Pept 1987; 19: 35-43.

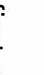


40 Schubert ML, Makhlouf GM. Gastrin secretion induced by distension is mediated by gastric and vasoactive intestinal peptide neurones in rats. Gastroenterology 1993; 104: peptide

41 Okuno M, Nakanishi T, Shinomura Y, Kiyohara T, Ishikawa $\mathrm{H}$, Tarui S. Peptide YY enhances $\mathrm{NaCl}$ and water absorption in the rat colon in vivo. Experientia 1992; 48: 47-50.

42 Ballantyne GH, Goldenring JR, Fleming FX, Rush J, Flin J, Fielding $\mathrm{P}$, et al. Inhibition of VIP-stimulated ion transport by a noval Y-receptor phenotype in rabbit distal colon. Am $\mathcal{F}$ Physiol 1993; 264: G848-54.
43 Knobloch SF, Diener M, Rummel W. Antisecretory effects of somatostatin and vasopressin in the rat colon descendens in vitro. Regul Pept 1989; 25: 75-85.

44 Hubel KA, Renquist K, Shirazi S. Ion transport in human caecum, transverse colon and sigmoid colon in vitro: baseline response to electrical stimulation of intrinsic nerves. Gastroenterology 1987; 92: 501-7.

45 Kuwahara A, Cooke HJ, Carey HV, Mekhijan H, Ellison EC, McGregor B. Effects of enteric neural stimulation on chloride transport in human left colon in vitro. Dig Dis Sci 1989; 34: 206-13. 